\title{
Personality and Personal Growth in the Working Midlifers
}

\author{
Nabamita Chakraborty, Sanjukta Das \\ Department of Psychology University of Calcutta \\ Department of Psychology University of Calcutta
}

\begin{abstract}
The current study attempted to explore midlife personal growth (generativity) and how it relates to the personality structure and domains of the working midlifers. The Loyola Generativity Scale, by McAdams \& de St. Aubin (1992) and The Neo Five Factor Inventory by Costa \& McCrae, (1984) were used. The sample comprised of 548 working male and female midlifers. The data were statistically analyzed by computing the Analyses of variance (ANOVA), post-hoc analyses, Pearson's Product-moment Correlation and Stepwise Multiple Regression Analyses (SMRA).Findings revealed a significant age and sex effect on the generativity. Generativity was significantly correlated to and significantly predicted by several of the personality variables in the current sample. Implications of the findings are mentioned herein.
\end{abstract}

Key words: Generativity, Big Five Factors, Middle adulthood, Personality, Personal Growth.

\section{Introduction}

Middle adulthood has not quite received substantial research attention. This may be due to the fact that midlife is indeed heterogeneous as a single life-phase. Relatively few studies have concentrated on the two decades from 40 to 60 years- the phase of midlife (Dorner, 2005), the corresponding important life-events attached to this phase and their interactions with the different dimensions of personality and self-development. A major proportion of this section of the population is still employed (Diehl \& others, 2001). These midlifers are often encountered with challenges such as career transitions, competing and battling against younger colleagues, facing declining career opportunities or retirement (Roberts \& Friend, 1998). Role changes are to be seen in the private life as well. This is the time when children are becoming adults and moving out leaving their parents in the "empty nest", alone with each other again (e.g., Crowley, Hayslip, \& Hobdy, 2003; Morfei, Hooker, Carpenter, Mix \& Blakely, 2004; Stewart \& Ostrove, 1998). As parents begin to show physical dependence one is bound to concentrate on one's care-giving responsibilities, one's own physical functioning becomes a concern (Dorner,et.al., 2005) when prominent signs of health deterioration start making their presence felt, like declining skeletal and muscular strength, declining sensory acuity, escalating probability of invasion of cardio-vascular disorders, and for women specifically the declining estrogen levels leading to menopausal symptoms pose dramatic challenges for the midlifers (e.g. Hooker \& Kaus, 1994; Klohnen \& others, 1996; Lachman, 2004; Staudinger \& Bluck,2001).From the above mentioned observations, a rather gloomy view of midlife is bound to conjure up in the mind. Yet while all these events can possibly be formidable physical and psychological stressors, it is also relevant to consider at this juncture that midlife is a time when, all our efforts in education, career, parenthood, partnership and social relations start coming to fruition.

Middle adulthood entails a formidable amount of social power and a luxurious supply of social support (Dorner et.al., 2005). Social satisfaction has been seen to be recording increments uniformly in this life-phase (e.g. Lansford, Sherman \& Antonucci, 1998). Naturally, the same also holds true for self-esteem which markedly increases and peaks around the age of 60 years (Robins,Trzesniewski, Tracy, Gosling \& Potter,2002), the "source of personal control and power" undergoes rapid enhancement (Clarke-Plaskie \& Lachman, 1999), and the experience of subjective well-being increases than what it was in the preceding life-phases (e.g. Cross \& Markus, 1991; Franz, 1994; Heckhausen, 1999) without "feeling overly grandiose or afraid" (Dorner et al, 2005). Most midlifers have adequately dealt with societal expectations and discovered "decent arrangements" to strike a balance of attention to personal goals along with environmental demands. However, middle adults show more egocentrism and more energetically follow their dreams and concerns than the older generations. (Mc Adams, 2001; Stewart \& Vandewater, 1998).

Generativity refers primarily to "the concern in establishing and guiding the next generation" (Erikson, 1950). According to the Psychoanalytical perspective, generativity is "the ability to loose oneself in the meeting of bodies and minds that leads to a gradual expansion of ego interests and to a libidinal investment in that which is being generated" (Erikson, 1950). According to Erikson's stages of personality development, care emerges as a virtue from the successful resolution of a conflict between generativity and stagnation during the period of midlife. D.P. McAdams had also focused on generativity, concern and commitment for future generations and 
developed a new model that draws on Erikson's theory, but makes significant departures from it. Rather than supposing that there is a specific stage of generativity in middle adulthood, McAdams suggests that generativity becomes an important issue at that time, because of increased cultural demand for it.

Generativity is an indispensable resource as far as culture and society are concerned. It is an extremely powerful psychosocial concept that can potentially generate social changes that would lead to social welfare as well as preserve values that would benefit the society and cultural heritage. The Oriental societies are collectivistic in nature. Unlike the Individualistic Western traditions, here most families are either joint or extended in nature. Often adult children also live as part of their parental families in the East, along with their own families, which is not very usual in the Western societal set-up. Thus it is all the more relevant to explore the psychosocial concept of generativity and how they are related to other important variables in these cultural contexts.

\section{Personality \& Generativity:}

Personality is a dynamic construct and keeps altering with experiences. The five major traits of personality are, Neuroticism, Extraversion, Openness to experience, Agreeableness and Conscientiousness.

Development beyond young adulthood is a contemporary conceptualization. According to early developmentalists, personality after young adulthood is impermeable to change (James, 1890). The psycho analytic viewpoint of development is child-centric and this tradition dates from Rousseau (1762/1948) and has been reinforced not only by the writings of Freud, but also by Piaget (1936/1974) and Bowlby (1982).

Initially motivated by the works of Erikson towards a view of development as a life-long process, research and theory over the past three decades, has moved beyond this child-centric approach (Lachman \& James, 1997) and culminated in a whole body of literature from a life-span perspective (e.g. Baltes, 1987; Baltes, Lindenberger \& Staudinger,1997; Featherman \& Lerner,1985; Lachman \& Baltes, 1994; Lerner, 1976). Although this entire transition realm of developmental research has made psychological development in older adulthood more lucid, it has done little to foster research of middle adulthood,(Lachman \& Bertrand, 2010).Compared with other age periods there is a definite dearth of research devoted to this life phase (Lachman \& James, 1997).

Much has been written about personality and the self in adulthood and old age (Bengston, Reedy \& Gordon, 1985, Neugarten, 1977). However, there has been little focus on the nature of personality and the self during the middle years of adulthood. Among those who have written about personality and self in the midlife perspectives, some have said that midlife is the peak time for adaptive functioning (e.g. Neugarten 1968); others have said that midlife is a tumultuous phase of life (e.g. Levinson, 1977). Another perspective presents midlife as a time of personality stability (Costa \& McCrae, 1994). However, evidence clearly indicates that the midlife experiences are prominently colored by early personality style and pattern (Lachman \& Bertrand, 2001).

\section{The Big Five Personality Factors:}

Comparisons were drawn between three different phases of adulthood on the Big Five traits. Crosssectional results divulged significant age differences on Agreeableness, Openness, Neuroticism, and Conscientiousness, (Markus \& Lachman, 1996). Agreeableness was found to increase with age, Conscientiousness peaked in midlife, Openness and Neuroticism decreased with the years. Gender differences dominated age differences. Women expressed a greater degree of Agreeableness, Extraversion, Conscientiousness as well as Neuroticism than men. Men expressed higher levels of Openness to experience.

Costa \& McCrae (e.g., 1994) expected that there would be no changes in the average levels of the Big Five personality factors after age 30, or that changes would slow down thereafter (McCrae \& Costa, 1990). However a number of recent studies have demonstrated that there are still significant changes after this point (e.g. McCrae et al, 2000; Srivastava, John, Gosling \& Potter, 2003: Helson \& Kwan 2000; Roberts, Robins, Caspi \& Trzesniewski, 2003: John \& Srivastava, 1999; Johnson et al, 1983; McCrae et.al, 1999; Wink \& Helson, 1993; Haan, Millsap, \& Hartka, 1986; Dudek \& Hall, 1991). Thus it is reasonable to expect changes in personality during middle adulthood.

The current research endeavor focused upon the personality development of midlifers in the Indian context. It is an effort to explore how personality and personal growth criss-cross each others' pathways during middle adulthood.

\section{Method}

\section{Objectives}

The first objective was to find out whether there is any effect of age and sex or the interaction between age and sex on the generativity and personality of the working male and female midlife adults. The second objective was to find out the nature of inter-relationships between the personality traits of Neuroticism, Extraversion, Openness to experience, Agreeableness and Conscientiousness and midlife generativity of the working male 
female midlifers. A final objective was to find out whether any of the above-mentioned personality traits contributed significantly to midlife generativity of the working midlifers.

\section{Participants}

A total of 700 midlifers were approached and requested to participate in the research. Out of these 700 individuals, 628 individuals consented to fill-up the research questionnaires that were thereafter distributed to them. Among these individuals, 547 individuals were actually able to fill-up and return the datasheets. The obtained datasheets, when screened for scoring and data analysis, revealed exactly 458 sets of questionnaires that were found to be flawlessly completed (none of the questionnaires had been incompletely filled up and none had been missed out or left unanswered.

Thus the finally available sample consists of 458 individuals, of which 255 are male and 203are female aged between 35 to 59 years. There are a few opinions that suggest a beginning of midlife sometime around the 35 year-old mark (Santrock,1997; Willis \& Martin,2005).Some recent research on midlife has also been conducted in the Indian socio-cultural backdrop assuming a beginning around the age of 35 years for both male and female participants (e.g. Bhattacharya \& Das, 2008; Chakraborty \& Das, 2010 \& 2012).

Purposive sampling was done. All the participants were selected from Kolkata and suburbs. The participants were selected on the basis of the following inclusion and exclusion criteria:-

\section{Inclusion Criteria:-}

$>$ The age has to be within $35-59$ years range

$>$ The individual has to be working in any organization for at least 3 years.

$>$ The individual has to be married, for at least 2 years.

$>$ Has to be a graduate at least.

$>$ Has become the parent of at least one child.

\section{Exclusion Criteria:-}

$>$ Any history of divorce or separation for at least one year due to marital discord.

$>$ Any history of past psychiatric consultation.

$>$ Any physical disability.

\section{Sample Description:}

The following table provides the detailed sample description in terms of the number of male and female participants available in each age group of midlife for the current research endeavour.

\begin{tabular}{|l|l|l|}
\hline $\begin{array}{l}\text { Age } \\
\text { Group I }\end{array}$ & $\begin{array}{l}\text { Age } \\
\text { group II }\end{array}$ & $\begin{array}{l}\text { Age group } \\
\text { III }\end{array}$ \\
\hline $\mathrm{N}=$ & $\mathrm{N}=$ & \multicolumn{1}{|c|}{$\mathrm{N}=$} \\
$\begin{array}{l}149 \\
\text { Male }=86\end{array}$ & $\begin{array}{l}174 \\
\text { Male }=\end{array}$ & $\begin{array}{l}\text { Male }=78 \\
\text { Female } \\
=63\end{array}$ \\
$\begin{array}{l}92 \\
\text { Female } \\
=82\end{array}$ & Female $=58$ \\
\hline
\end{tabular}

\section{Information Schedule:}

Tools used

The information schedule contained all possible kinds of information relevant to the present research area. Identification data was deliberately omitted from the information schedule as people are not particularly eager to disclose their identities when it comes to exposing their marital relationship, marital happiness conjugal relationship and such other areas. Society (particularly the people born more than 50 years ago, as the sample includes the birth cohort from 1950-1965), is still pretty much sensitive and touchy regarding these issues. Thus nobody in the sample was asked about their identification details. Age, sex, marital status, education and academic achievement, occupational status, number of children, duration of work and married life, personal income, and some contact information were the major information sought. Apart from this, history of marital discord or separation or divorce was taken into account; history of psychiatric consultation or physical disability was also included in the information schedule.

\section{The Loyola Generatively Scale (McAdams and de St. Aubin, 1992).}

The Loyola Generativity Scale was developed by McAdams and de St.Aubin (1992) in order to measure individual differences in generativity. The scale is composed of 20 statements. Cronbach's alpha coefficient for the LGS in studies conducted in Western samples is .83 suggesting a high internal consistency. The Cronbach's alpha coefficient for LGS in the current sample is .80 , which is also indicating very high internal consistency. 
The scale is composed of 20 statements, for example "I have important skills that I try to teach others" and "I feel I have done nothing that will survive after I die".

NEO-Five Factor Inventory (McCrae and Costa, 1992): The Neo Personality Inventory was developed by Paul.T.Costa \& Robert R. McCrae. There are two versions of the Neo PI-R: Form S for self-report and Form-R for observer ratings. The former consists of 240 items answered on a 5-point scale which is self-administered and appropriate for men and women of all ages. The latter is a "companion instrument" with 240 parallel items written in a third person for peer spouse or expert ratings.

The Development and validation of the Neo-FFI: The Neo-FFI was developed as a shorter version of the Neo-PI. Although new norms were provided, the scale itself remained unchanged. This shorter revision of the NEO- PI has been used in the current study as a self-report measure. For the NEO FFI (the 60 item domain only version) the internal consistencies reported in the manual were: $\mathrm{N}=.79, \mathrm{E}=.79, \mathrm{O}=.80, \mathrm{~A}=.75, \mathrm{C}=.83$.

Some simple examples of questions asked by the Neo-FFI (Form-S) are these, "I am not a worrier", "I like to have a lot of people around me", "I don't like to waste my time daydreaming", "I try to be courteous to everyone I meet", "I keep my belongings clean and neat".

\section{Procedure}

At the initial stage, of the research, the data sheets to be filled up by the informants were prepared. An information schedule was prepared that contained all the relevant socio-demographic information about the participants. After that, the questionnaires assessing the variables of generativity, personality, self-efficacy, narcissism, psychiatric morbidity and marital quality were gathered and ordered in a predetermined sequence. All the 700 datasheets were arranged.

The next step was to make a list of the possible workplaces (government organisations, banks, schools and colleges) from which the necessary working, middle adults could be reached for data collection. One by one, these workplaces were visited and the employees were informed about the purpose of the visit. In case of a school or college, the head of the institution was approached and permission was obtained for data collection. The target age-range (35-59 years) was disclosed to all the employees along with the inclusion and exclusion criteria. Among the individuals fulfilling the criteria, only those who consented to participate in the research and showed signs of eagerness were handed out the data sheets.

The participants for the research work were selected in accordance with the inclusion and exclusion criteria from Kolkata and suburbs. Questionnaires were administered to consenting subjects and confidentiality was assured.

\section{Statistical Analysis}

The obtained data were analyzed, using appropriate statistical techniques. For statistical analysis the available statistical package (SPSS 16) has been used. The mean (M) scores and the standard deviations (SD) were computed for the male and female midlifers and for the three different age groups of midlife with respect to all the variables included in the research. Then, two-way analysis of variance (ANOVA) was done to find out the significance of difference between the means of the male and female midlifers and the three age groups of midlife. The ANOVA was complemented by Post-hoc analyses using Tuckey test for multiple comparisons between means in each of the variables. This was followed by the computation of correlation coefficients using (Pearson's Product- Moment method) to find out the magnitude and direction of association between the different constructs of Neuroticism, Extraversion, Openness to experience, Agreeableness, Conscientiousness, and generativity of the midlife adult participants This correlation coefficient was computed separately for the two sexes (male and female ) and the three age groups of midlife. Finally, Stepwise Multiple Regression Analysis (SMRA) was done to find out which variables (Neuroticism, Extraversion, Openness to experience, Agreeableness, and Conscientiousness) made significant contributions to midlife generativity. This was initially done on the total group of midlifers and finally separately for the two sexes and three different age groups.

\section{Results}

The statistical analyses reveal that the mean generativity scores of the male midlifers of the first age group or Age Group -1(35-39 years) is 33.07 and SD of this age group is 7.82. The generativity score of the third age group (50-59 years) is 31.58 lesser than the first age group, and SD value is 8.55. Age group 2 (40-49 years) experiences the maximum generativity and the mean score of this age group is 33.97 and the SD value is 9.38. For the female midlifers, the mean generativity score for age group 1 is 31.60 and SD value is 6.81 , that of age group 3 is 36.14 and the SD value of this age group is 7.46. Finally, the mean generativity score of age group 2 is 36.63 and the $\mathrm{SD}$ value of this age group is 9.33 .

The results also reveal that the male midlifers' mean scores on the Big Five Personality factors of Neuroticism is 22.20, Extraversion is 27, Openness to Experience is 23.92, Agreeableness is 26.07 and 
Conscientiousness is 30.80 for Age-group-1 (35-39 years).The SD values of the above factors for this particular age group are, 4.59, 4.2, 4.16, 4.35 and 4.71 respectively. The mean personality factor scores for male midlifers of age group 2 are, 21.78 (Neuroticism), 27.04 (Extraversion), 24.08 (Openness to experience), 26.43(Agreeableness) and 30 (Conscientiousness) The standard deviations for the above factors are, 7.40, 4.96, $4.09,4.29,7.06$. Finally, the mean personality domain scores for the male midlifers of age group 3 for the factors of $\mathrm{N}, \mathrm{E}, \mathrm{O}, \mathrm{A}$ and $\mathrm{C}$ are $22.08,24.36,24,27.01$ and 28.79 respectively.

The Standard deviation values are 4.86, 4.53, 4, 4.82, 6 respectively for the factors of N, E, O, A and C.

For the females of age group 1, mean scores on the Big Five personality factors are $24.30(\mathrm{~N}), 25.05$ (E),24.95 (O), $26.05(\mathrm{~A})$, and 28.63 (C).The Standard deviation scores of the age group 1 females are, 6.30, 6.20, $5.47,4.40$ and 5.85 respectively. For the females falling in the age group 2 of midlife (40-49 years), the mean scores on the five personality domains are, $22.89(\mathrm{~N}), 25.50(\mathrm{E}), 26.02(\mathrm{O}), 28.29(\mathrm{~A})$ and $30.65(\mathrm{C})$, with SD values of $6.26,5.32,5.61,5.56$ and 7.19 respectively. For the last age group of the female midlifers (50-59 years), the mean scores on the personality factors are $21.51(\mathrm{~N}), 26.16(\mathrm{E}), 25.84(\mathrm{O}), 29.16(\mathrm{~A})$, and $32.67(\mathrm{C})$. The SD values for the above factor means are 7.31, 5.25, 5.17, 6.17, and 7.02 for the five factors respectively.

It can be seen that generativity is significantly different among the male and female midlifers. Generativity scores also vary significantly among the three age groups of middle adulthood. There is also a significant agesex interaction effect on the generative concern of the midlifers.

It can be observed that a significant difference exists between Age group 1 and 2 of middle adulthood on the generative concern expressed.

The results show that there is no significant mean difference between the male and female midlifers with regard to their level of neuroticism (2.25), and there is no significant difference between the three age-groups with regard to their level of neuroticism (1.98). There is also no significant age-sex interaction effect on the level of neuroticism of the midlifers (1.63). The results reveal that the male and female midlifers are not significantly different on the construct of Extraversion (1.14). There is no significant difference among the three age-groups of midlife (1.46). There is a significant age-sex interaction effect on the Extraversion at midlife (5.14). The male and female midlifers are significantly different on the construct of Openness to experience (13.91** significant at 0.01 level). There is no significant age effect or age-sex interaction effect (.72 and .48 respectively). There is a significant male -female difference with regard to the construct of Agreeableness (8.24 significant at 0.01 level), and there is a significant difference between the age-groups with regard to their level of Agreeableness (6.23 significant at 0.01 level of significance). Age group 1 and age group 2 are significantly different in terms of their level of Agreeableness. There is a significant age-sex interaction effect on the level of Conscientiousness at midlife $(8.32 * *)$.

Results also indicate that several of the personality variables significantly correlate to midlife generativity at the different age groups of midlife. The Pearson's Product-moment correlation coefficients expressing the magnitude and direction of relationship between generativity and the rest of the variables reveal that, at age group 1 of the female midlifers generativity is significantly positively correlated to Extraversion and Conscientiousness. At age group 2, generativity is positively correlated to Extraversion, Conscientiousness, and Openness to experience. At age group 3, generativity is positively correlated to Extraversion, Conscientiousness of female midlifers. At age group 1 of the male midlifers' generativity is significantly positively correlated to Conscientiousness $(.355, \mathrm{p}<0.01)$, Agreeableness $(.245, \mathrm{p}<0.05)$. At age group 2, generativity is positively correlated to Conscientiousness (.422, $\mathrm{p}<0.01$ ), Agreeableness (.267, $\mathrm{p}<0.01)$, Extraversion (.332, $\mathrm{p}<0.01)$ At age group 3, generativity is positively correlated to Extraversion (.223, $\mathrm{p}<0.05)$, and Agreeableness (.234, $\mathrm{p}<0.05)$ of the male midlifers.

From the Stepwise Multiple Regression Analysis (SMRA) representing the variables contributing significantly to the generativity of the male midlifers belonging to the age group 1 (35-39 yrs), Age group 2 (40$49 \mathrm{yrs}$ ) and age group3 (50-59years), it is observed that, among the male midlifers generativity is significantly positively contributed to by the variables of Conscientiousness (beta value $=.368$ ) at age group1, Conscientiousness (beta value $=.300$ ) at age group 2 and positively significantly contributed to by Openness to experience (beta value $=.220$ ) at age group 3 . At age group 1 , for the female midlifers, the predictor variables significantly positively contributing to generativity are Extraversion (beta value $=.426$ ). At age group 2 the significant contributing variable to generativity is Openness to experience (beta value $=.237$ ),

\section{Discussion}

Most of the researchers grappling with the extremely complex phenomena entailed by the phase of midlife have come up with myriad contradictions in their conclusions (Heckhausen, 2001). While the men at midlife, are entangled in the despondent intricacies of the "midlife crisis" (Jacques, 1965), women are caught up in the depressive feelings emerging from "empty nest syndrome" (Borland, 1982) or the bio-psychological and psycho-endocrinological effects of menopause (Sheehy, 1992), or struggle to tackle the multiple role responsibilities being the "sandwiched generation" entails with it (Brody, 1990). As a striking contrast, several 
studies have found midlifers to experience decreasing psychological symptoms (Aldwin, et al, 1989; Kessler et al 1992), heightened marital satisfaction, overall enhanced "life satisfaction and mastery" (Keyes \& Ryff, 1999) as well as reporting comfortably healthy spirits (Merrill \& Verbrugge, 1999).

It is crucially relevant to resolve and adequately clarify these contradictions to illuminate the controversial aspects of midlife coping and enlighten ourselves with regard to the adaptational strategies adopted by the midlifers. Some researchers have hypothesized that the middle adults, have become "expert copers", coping with life's challenges with above average proficiency (Aldwin \& Levenson, 2001).Taking off from this background and considering the socio-cultural impact on the working midlifers of the geographical area under consideration the current investigation has been undertaken.

\section{Generativity}

\section{Discussion on the group differences}

The results from the current statistical analyses reveal that for both the male and female midlifers living and working in this social and cultural set-up generativity reaches a peak during the second division of midlife (40 to 49 years) (as shown by Table-1).

Table1: Showing the mean and standard deviation values of the male and female middle adult participants belonging to the three different age-groups on generativity.

\begin{tabular}{|l|l|l|l|l|l|l|l|l|l|l|}
\hline & Male & & Total(Male) & & Female & & $\begin{array}{l}\text { Total } \\
\text { (Female) }\end{array}$ & & $\begin{array}{l}\text { Total } \\
\text { (Male } \\
\& \\
\text { Female) }\end{array}$ & \\
\hline & M & SD & M & SD & M & SD & M & SD & M & SD \\
\hline $\begin{array}{l}\text { Age } \\
\text { Group-1 }\end{array}$ & 33.07 & 7.82 & 32.93 & 8.65 & 31.60 & 6.81 & 34.93 & 8.36 & 33.82 & 8.57 \\
\hline $\begin{array}{l}\text { Age } \\
\text { Group-2 }\end{array}$ & 33.97 & 9.38 & & & 36.63 & 9.33 & & & & \\
\hline $\begin{array}{l}\text { Age } \\
\text { Group-3 }\end{array}$ & 31.58 & 8.55 & & & 36.14 & 7.46 & & & & \\
\hline
\end{tabular}

Figure- 1: Graphical representation of the mean and standard deviations of generativity of the male and female midlifers belonging to the three different age groups (Age groups1, 2 and 3).

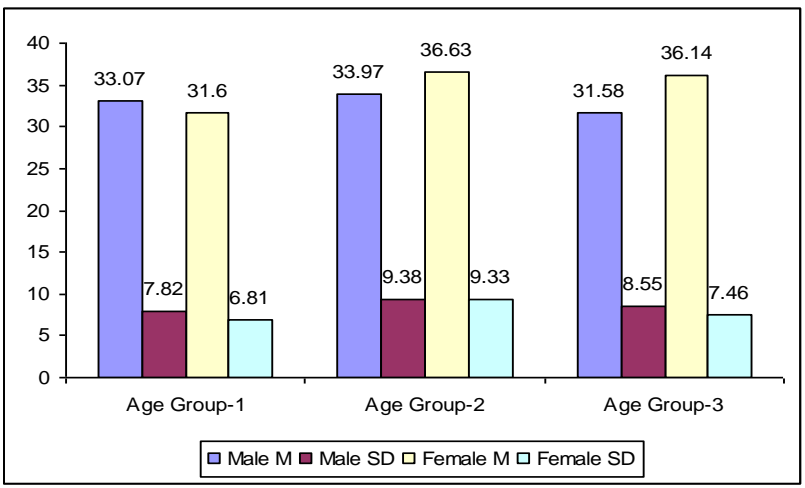

From the ANOVA tables, it is seen that the level of generativity is significantly different among the working male and female midlife participants (as shown by table-3).In fact the three distinct age groups of midlife are also significantly different in the levels of generativity experienced by them (table- 3). There is also a significant age-sex interaction affecting the levels of generativity reported by the working midlifers of Kolkata and suburbs (table-3).

Table 3: Two-way ANOVA showing the effects of sex, age and their interaction on the generativity of the midlifers.

\begin{tabular}{|l|l|l|l|}
\hline $\begin{array}{l}\text { Source of } \\
\text { variation }\end{array}$ & $\begin{array}{l}\text { df } \\
\text { value }\end{array}$ & $\begin{array}{l}\text { Mean } \\
\text { Square }\end{array}$ & F-ratio \\
\hline sex & 1 & 411.660 & $5.84^{*}$ \\
\hline Age & 2 & 347.942 & $4.93^{* *}$ \\
\hline Interaction & 2 & 336.581 & $4.77^{*}$ \\
\hline error & 453 & 70.535 & \\
\hline
\end{tabular}

$*(\mathrm{p}<0.05) ; * *(\mathrm{p}<0.01)$ 
Table 4: Showing the post-hoc analyses to indicate which age group of midlifers differs significantly from which other age group on the variable of generativity.

\begin{tabular}{|l|ll|l|}
\hline $\begin{array}{l}\text { Tukey } \\
\text { HSD }\end{array}$ & I & J & $\begin{array}{l}\text { Mean } \\
\text { difference }\end{array}$ \\
\hline & 1 & 2 & $-2.77^{* * *}$ \\
\hline & & 3 & -1.07 \\
\hline & 2 & 3 & 1.70 \\
\hline
\end{tabular}

$*(\mathrm{p}<0.01)$;

The mean values of generativity indicate that the working female midlifers are more generative than the working male midlifers (table-1). As far as the significant effect of age is considered, age group 1 has scored the least in generativity; age group 2 has reported experiencing the maximum levels of generativity (table-1). Thus it can be claimed from these findings that the changes and shifts associated with the socio-emotional make-up of midlife are definitely not prominent in the 35-39 year age range. Rather these changes come about and become somewhat predominant in the age group 2 or the 40 to 49 year age range. This finding has also been corroborated by previous research in this field (Chakraborty \& Das, 2012).

Research work relating to generativity has mostly concentrated on male development (Levinson, 1977,1986; Snarey, 1993; Snarey et.al., 1987; Vaillant, 1977; Vaillant \& Milofsky, 1980). In previous research, women with more education defined themselves as more generative, than did less educated women; - however higher education did not bring about more generativity in men. Women scored significantly higher than men on generativity by providing others with emotional support and via obligations to family and friends. Peterson \& Klohnen (1995) claimed that generative women express pro-social personality characteristics, generative work attitudes, have deeper sacrifices and investments in the parenting role, and an "expanded radius of care." These findings may be possible explanatory hypotheses for the greater female generativity revealed from the current analyses.

Some studies of generativity by contrast, have typically not found gender effects in mean levels (Mc Adams et al, 1998); different measures of generativity provide different results in this regard (Mc Adams, 2001). However, Mc Adams \& de St. Aubin (1992) reported that the inter- relation of gender and parenting role predicted scores on the Loyola Generativity Scale (LGS) the scale that has been used in the present research as well. Men who had never been fathers scored especially low in generativity whereas men who had at one time or another been fathers scored relatively high. For women, the parenting role was not significantly associated with generativity scores. Thus here a small discrimination might be made between the male and female participants on a theoretical platform. The female midlifers can be described as being biologically generative (which relates to conceiving, bearing and raising an infant, the generative object) (Kotre, 1984), with or without the feelings and attachments originating from parenthood. Whereas men, who recorded marked enhancements in generativity only after becoming parents, might have a more explicit inclination towards parental generativity where they nurture and discipline offspring, initiate them into family tradition, and continue to support, guide, and protect, teach, and advise them through their adolescent years; the generative object, thus, is the child (Kotre, 1984). The current sample includes male and female midlifers who have parented at least one child, and have acquired the experience of parental generativity, but in addition to that, as all the females underwent the child-bearing experience, they can also be thought to be biologically generative.

Another tentative explanation might be that, the sample chosen for the current research included only educated and working women, and this might account for their higher mean generativity scores compared to the men. Previous studies show that adherence to the social clock alone-that is, without taking into account congruence with individual aspirations - neither fosters successful adjustment nor promotes personality growth. In fact, to keep in tune with the social clock, despite feelings of dissatisfaction with the current situation, turned out to be destructive in terms of both aspects. However, if societal expectations can be brought in line with personal needs and goals, competence and adjustment result. Finally, personal growth had no relationship with social clock adherence, but it did have a relationship with the occurrence and mastery of life-course challenges. Taken together, conforming to societal expectations can support well-being if it corresponds to personal needs and goals; however, for personal growth, it seems to be of higher importance to seek and master challenges embodied sometimes by the very transcendence of social norms. Thus the present working sample of women, as they have followed their own careeristic ambitions and simultaneously conformed to the social clock expectations, they have perhaps achieved higher personal growth in the years after the 40 year mark. Before that, there might have been a period of confusion and dilemma between social norm conformity and personal ambitions or goals, and thereby personal suffered a setback then.

Moreover, women in this cultural background are also more involved in family and care-giving activities, and providing emotional support than men. Hence, this might be interpreted to be a manifestation of the communal mode of generativity, as involving nurturance and care for others. 
"In terms of personal growth, social clock adherence does not seem to offer any advantages" (Helson \& Wink, 1987); in fact it even turns out to be "detrimental when associated with a lack of challenges" (e.g., keeping up the conventional homemaking role; Helson \& Roberts, 1994). Thus, coping with challenges facilitates personal growth for those women who pursue professional careers "independent from whether they had partners, children, or both or were single women" (Helson \& Roberts, 1994; Stewart \& Ostrove, 1998).The current working women participants with higher generativity might also experience heightened expressions of technical generativity that is the adult teaches skills and offers instrument training to those who require these competencies for successful adaption to the world; the generative object are both the skill itself and the apprentice for the skill, resultant from their successful professional careers, combined with a reflection of the agentic mode of generativity, encompassing creative and powerful extensions of the self (Kotre, 1984.).

\section{The Big Five Personality Factors:}

The mean scores of both the male and female working midlife participants belonging to the three different age groups have been summarized in Table -2.

Table.2a: Showing the means (M) and standard deviations (SD) of the male and female middle adults belonging to the three different age groups on the constructs of Neuroticism (N), Extraversion (E), Openness to experience (O), Agreeableness(A) and Conscientiousness (C).

\begin{tabular}{|l|l|l|l|l|}
\hline & Male & & Female & \\
\hline $\begin{array}{l}\text { Age } \\
\text { Group } \\
1\end{array}$ & M & SD & M & SD \\
\hline N & 22.20 & 4.59 & 24.30 & 6.30 \\
\hline E & 27.00 & 4.2 & 25.05 & 6.20 \\
\hline O & 23.92 & 4.16 & 24.95 & 5.47 \\
\hline A & 26.07 & 4.35 & 26.05 & 4.40 \\
\hline C & 30.80 & 4.71 & 28.63 & 5.85 \\
\hline $\begin{array}{l}\text { Age } \\
\text { Gr.2 }\end{array}$ & & & & \\
\hline N & 21.78 & 7.40 & 22.89 & 6.26 \\
\hline E & 27.04 & 4.96 & 25.50 & 5.32 \\
\hline O & 24.08 & 4.09 & 26.02 & 5.61 \\
\hline A & 26.43 & 4.29 & 28.29 & 5.56 \\
\hline C & 30.00 & 6.16 & 30.65 & 7.19 \\
\hline $\begin{array}{l}\text { Age } \\
\text { Gr.-3 }\end{array}$ & & & & \\
\hline N & 22.08 & 4.86 & 21.51 & 7.31 \\
\hline E & 24.36 & 4.53 & 26.16 & 5.25 \\
\hline O & 24.00 & 4.00 & 25.84 & 5.17 \\
\hline A & 27.01 & 4.82 & 29.16 & 6.17 \\
\hline C & 28.79 & 6.00 & 32.67 & 7.02 \\
\hline
\end{tabular}

Table $2 \mathrm{~b}$ showing Mean scores on Personality domains before gender division.

\begin{tabular}{|c|c|c|c|c|c|c|c|c|}
\hline & $\begin{array}{l}\text { Age grp- } \\
\frac{1}{M}\end{array}$ & SD & $\begin{array}{l}\text { Age grp- } \\
\frac{2}{M}\end{array}$ & SD & $\frac{\text { Age grp-3 }}{M}$ & SD & $\frac{\text { Total }}{\mathrm{M}}$ & SD \\
\hline Neuroticism & 23.09 & 5.46 & 22.30 & 6.95 & 21.84 & 5.99 & 22.42 & 6.22 \\
\hline Extraversion & 26.13 & 5.82 & 26.33 & 5.18 & 25.12 & 4.91 & 25.91 & 5.33 \\
\hline Openness to experience & 24.36 & 4.52 & 24.99 & 4.95 & 24.72 & 4.59 & 24.71 & 4.70 \\
\hline Agreeableness & 26.06 & 4.22 & 27.31 & 5 & 27.92 & 5.52 & 27.08 & 4.97 \\
\hline Conscientiousness & 29.89 & 5.31 & 30.28 & 6.66 & 30.42 & 6.71 & 30.19 & 6.25 \\
\hline
\end{tabular}

It can be seen from the ANOVA tables that, Neuroticism did not show any significant age, sex or interaction effect (as shown by table-5), that is the scores on Neuroticism are not very different when the three different age groups are considered separately when understanding midlife personality development. 


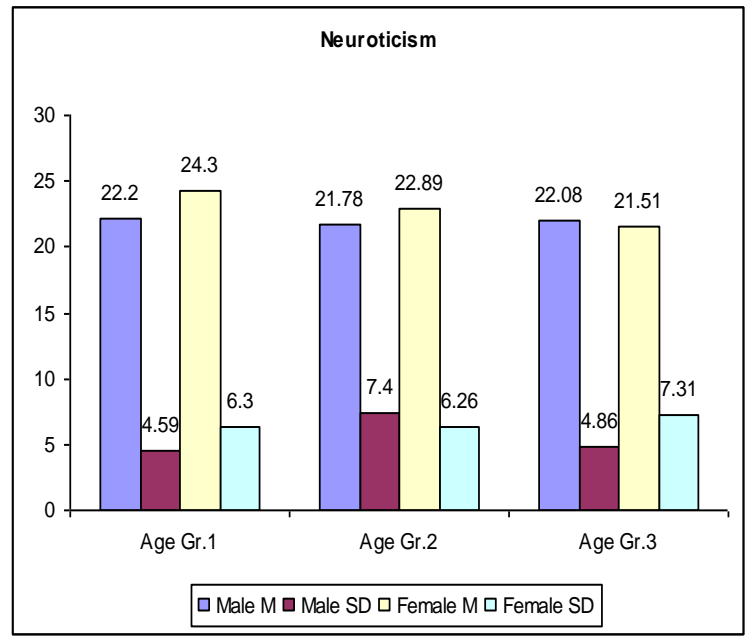

Figure- 2: Graphical representation of the mean and standard deviations of Neuroticism of the male and female midlifers belonging to the three different age groups (Age groups1,2 and 3).

It was not significantly correlated to generativity for any of the male or female midlifers of the three different age-groups (as shown by Tables $11 \& 12$ ).

Table 5: Showing the effect of sex, age and their interaction on the Neuroticism of the midlifers.

\begin{tabular}{|l|l|l|l|}
\hline $\begin{array}{l}\text { Source of } \\
\text { variation }\end{array}$ & $d f$ & $\begin{array}{l}\text { Mean } \\
\text { square }\end{array}$ & F-ratio \\
\hline Sex & 1 & 86.34 & 2.25 \\
\hline Age grouping & 2 & 75.95 & 1.98 \\
\hline Interaction & 2 & 62.69 & 1.63 \\
\hline Error & 452 & 38.39 & \\
\hline
\end{tabular}

Extraversion showed a significant age-sex interaction effect but no significant independent effect of age or sex was found from the current analyses (as shown by table-6).

Table 6: Two-way ANOVA showing the effect of sex, age grouping and their interaction on the Extraversion of the midlifers.

$* *(\mathrm{p}<0.01)$

\begin{tabular}{|l|l|l|l|l|}
\hline & $\begin{array}{l}\text { Source of } \\
\text { variation }\end{array}$ & $d f$ & $\begin{array}{l}\text { Mean } \\
\text { square }\end{array}$ & F-ratio \\
\hline Extraversion & sex & 1 & 31.74 & 1.14 \\
\hline & Age & 2 & 40.44 & 1.46 \\
\hline & Interaction & 2 & 142.74 & $5.14^{* *}$ \\
\hline & Error & 452 & 27.75 & \\
\hline
\end{tabular}

Extraversion is significantly positively correlated to both male (Age grp-2 \& 3) and female (Age grp-1 \& 2) generativity and significantly contributes to female generativity at age groups 1 and 2 (as shown by Table 11 , 12,13 \& 14). Previous research indicates (Helson \& Kwan, 2000), that Extraversion does not involve a clear pattern of mean-level changes unless the two constituent elements of "Social Vitality" and "Social Dominance" are considered separately. "Social Dominance" reflecting "independence, dominance and self-confidence" increases with age. "Social Vitality", reflecting features of "sociability, positive affect, gregariousness and energy level" decreases with age (Roberts, et.al., 2003). For the males Extraversion is found to have undergone a non-significant decrease at the 50-59 year age-range, whereas for the females, Extraversion scores have undergone increases at age-groups 2 and 3 (as shown by Figure-3). 


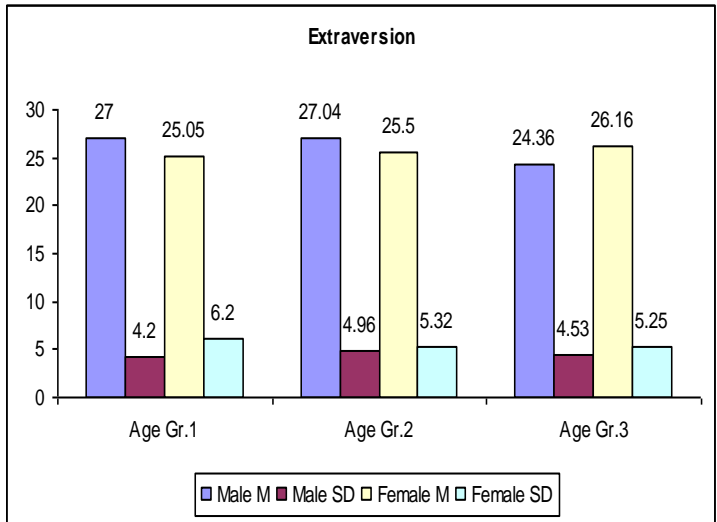

Figure- 3: Graphical representation of the mean and standard deviations of Extraversion of the male and female midlifers belonging to the three different age groups (Age groups1, 2 and 3).

Openness to experience is significantly different among the male and female midlifers (as shown by table- 7).

Table 7: Showing the effect of sex, age grouping and their interaction on the Openness to experience of the

\begin{tabular}{|l|l|l|l|l|l|}
\hline & $\begin{array}{l}\text { Source of } \\
\text { variation }\end{array}$ & $\begin{array}{l}\text { df } \\
\text { value }\end{array}$ & $\begin{array}{l}\text { Mean } \\
\text { Square }\end{array}$ & F-ratio \\
\hline $\begin{array}{l}\text { Openness to } \\
\text { experience }\end{array}$ & sex & 1 & 299.92 & $13.91^{* *}$ \\
\hline & Age & 2 & 15.41 & 0.72 \\
\hline & Interaction & 2 & 10.26 & 0.48 \\
\hline & error & 452 & 21.57 & \\
\hline
\end{tabular}

$* *(\mathrm{p}<0.01)$

The female working midlifers are higher in openness to experience than the male working midlifers. This higher openness to experience might account for the greater levels of generativity in the women. Openness to experience is a significant predictor of working female midlife generativity at age group 2 and is significantly correlated to female generativity at the same age group. For the working males, although the magnitude of correlation is increasing with each age group, the critical value for a significant coefficient of correlation could not be exceeded (as revealed by Table-12). Openness predicts generativity significantly at age group 3 for the male working midlifers. Openness to experience entails "active imagination, aesthetic sensitivity, preference for variety, intellectual curiosity and independence of judgment". Open individuals are "curious about both the inner and outer worlds and their lives are experientially richer. They experience particularly higher levels of divergent thinking that contribute to creativity" (McCrae,1987).

Previous research established that Openness to experience decreases with age (McCrae et.al., 1999; Srivastava et.al., 2003). However, the current findings show Openness to experience to be increasing with age (as shown by table-2 and Figure-4).

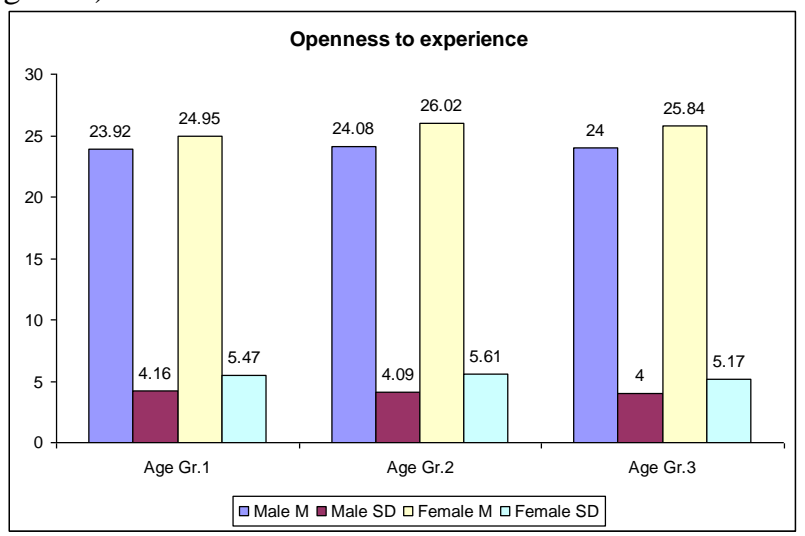

Figure- 4: Graphical representation of the mean and standard deviations of Openness to experience of the male and female midlifers belonging to the three different age groups (Age groups1,2 and 3).

Openness to experience is particularly significantly correlated to female generativity at age grp-2. This might be a reflection of cultural specificity. The process of ageing is more positively perceived in the current 
societal context; hence in spite of the vehement emphasis on concepts like "the empty nest syndrome", "midlife crisis", degenerating physical beauty, declining sexual prowess, menopause and such others given by several other pioneering research works conducted abroad (Crowley, Hayslip, \& Hobdy, 2003; Morfei, Hooker, Carpenter, Mix \& Blakely,2004; Stewart \& Ostrove,1998; Hooker \& Kaus,1994; Klohnen \& others, 1996; Lachman, 2004; Staudinger \& Bluck,2001), which obviously render a rather gloomy view of middle adulthood, personal growth along with age is quite evident in the research findings obtained from this context (Bhattacharya \& Das, 2008). A theoretical perspective that might substantiate this, is that of Peck (1956), who had theorized adult development to be progressing by overcoming a few crises like valuing wisdom versus valuing physical power, or "socializing versus sexualizing". The cultures wherein a heavy positive connotation is attached to physical vitality might bring about crisis experiences in midlifers. However, the Indian culture emphasizes much more on the enrichment of the self and growth or impoverishments associated with the self rather than the physical strengths.

Agreeableness has been found to be significantly different in the working middle adult men and women (as shown by table-8) as well as significantly different among age groups 1 and 3 (as shown by Table-9).

Table 8: Two-way ANOVA showing the effects of sex, age and their interaction on the Agreeableness of the midlifers.

\begin{tabular}{|l|l|l|l|l|}
\hline & $\begin{array}{l}\text { Source of } \\
\text { variance }\end{array}$ & $\begin{array}{l}\text { df } \\
\text { value }\end{array}$ & $\begin{array}{l}\text { Mean } \\
\text { square }\end{array}$ & F-ratio \\
\hline Agreeableness & sex & 1 & 195.81 & $8.24 * *$ \\
\hline & Age & 2 & 148.20 & $6.23 * *$ \\
\hline & Interaction & 2 & 50.22 & 2.11 \\
\hline & Error & 452 & 23.77 & \\
\hline
\end{tabular}

$* *(\mathrm{p}<0.01)$

Table 9: Showing the post-hoc analyses to indicate which age group of midlifers differs significantly from which other age group on the variable of Agreeableness

\begin{tabular}{|l|ll|l|}
\hline $\begin{array}{l}\text { Tukey } \\
\text { HSD }\end{array}$ & I & J & $\begin{array}{l}\text { Mean } \\
\text { difference }\end{array}$ \\
\hline & 1 & 2 & -1.25 \\
\hline & & 3 & $-1.86^{* *}$ \\
\hline & 2 & 3 & -.61 \\
\hline
\end{tabular}

$(\mathrm{p}<0.01)$

Working women are more agreeable than working men at midlife as per the current findings. Agreeableness is significantly correlated to generativity at age group 2 for the females. However, Agreeableness is significantly correlated to generativity at all age groups of the male midlifers. Thus the "fundamentally altruistic tendencies, sympathy and eagerness to help others", which are normal entailments of the construct of Agreeableness, might help in the process of being generative for the middle adult females. Previous research has established that females at midlife are intrinsically more altruistic in nature and this facilitates their generative thoughts (Peterson \& Klohnen, 1995).Furthermore, the intrinsic tendencies of warmth, trust, altruism and sympathy towards others, perhaps would enhance the capacity for acceptance of the perspectives of others as well as recognizing that others' perspectives are equally significant, valuable as well as unique. Previous research findings (Wink \& Helson, 1993; Haan, Millsap, \& Hartka, 1986; Dudek \& Hall, 1991) indicate that Agreeableness increases with age. These findings are corroborated by the present research as well (as shown by Figure-5).

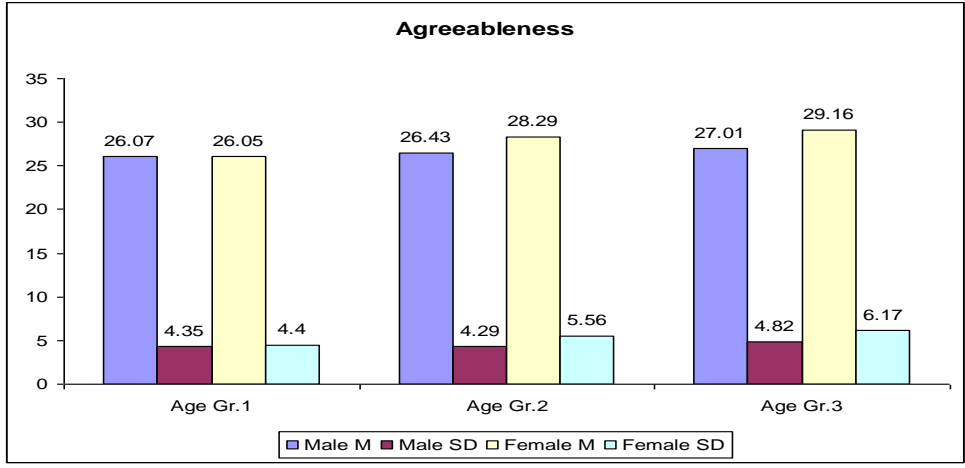

Figure- 5: Graphical representation of the mean and standard deviations of Agreeableness of the male and female midlifers belonging to the three different age groups (Age groups1, 2 and 3). 
In the age of multi-culturalism and multi-perspectivism, the simultaneous existence of several perspectives pervades the educated mind. Since our current participants are all educated at least up to a certain standard and have considerable exposure to the various styles of living, their exposure and education might explain the higher Openness to experience as well as Agreeableness of this sample.

Conscientiousness has a significant age- sex interaction effect, (as shown by table- 10) but no independent effect of age or sex. Conscientiousness entails the features of "purposefulness, persistent striving towards a goal, and being strong-willed and determined". For the female midlifers, the score on Conscientiousness is found to increase with age (Table-2). Moreover, it is significantly correlated to generativity at all age groups of midlife (as shown by Table- $11 \& 12$ ). This Conscientiousness is utilized by them for pursuing their life-goals and performing the role requirements and bearing the burdens of midlife responsibilities. As per the findings they become more self-controlled, persistent, striving and norm-oriented (Helson \& Kwan, 2000) with the passing of each age group, and this facilitates their success in fulfilling the job-demands both outside and inside the house as well as making room in the mind for generative contemplations. These contemplations when undertaken inside the home or within the family (in the form of kin-keeping or care-giving responsibilities) become communal generativity (Kotre, 1984); similarly, when undertaken in the professional area conscientiously, become a form of agency (Kotre, 1984), encompassing powerful and creative extensions of the self.

Table 10: Showing the effect of sex, age grouping and their interaction on the Conscientiousness of the midlifers.

\begin{tabular}{|l|l|l|l|}
\hline $\begin{array}{l}\text { Source of } \\
\text { variation }\end{array}$ & $d f$ & $\begin{array}{l}\text { Mean } \\
\text { Square }\end{array}$ & F-ratio \\
\hline sex & 1 & 71.59 & 1.88 \\
\hline Age & 2 & 35.55 & .94 \\
\hline Interaction & 2 & 316.49 & $8.32^{* *}$ \\
\hline error & 452 & 38.02 & \\
\hline
\end{tabular}

$* *(\mathrm{p}<0.01)$

The male Conscientiousness decreases non-significantly with age or perhaps plateaus in midlife as predicted by previous research (Costa et.al., 2000).Interestingly, the working males begin midlife with a higher level of Conscientiousness than the working females (as shown by figure-6).

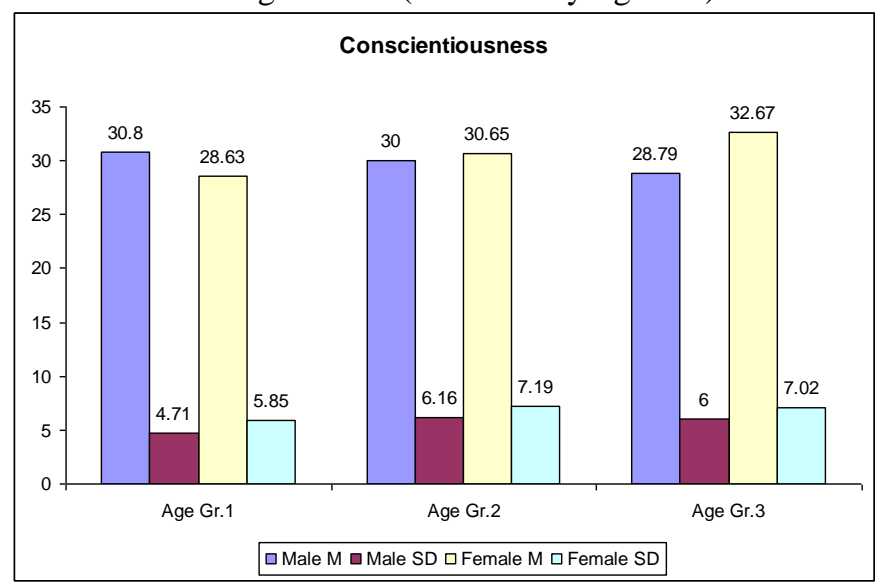

Figure- 6: Graphical representation of the mean and standard deviations of Conscientiousness of the male and female midlifers belonging to the three different age groups (Age groups1, 2 and 3).

Conscientiousness is maximally correlated to generativity in working males at Age group 2 and significantly predicts generativity at both age groups 1 and 2. Possibly the heavypressure of normative societal expectations about beginning and continuing to become the bread-winner for the family makes them highly Conscientious at their efforts to fulfill their job-demands. With age however, this pressure mollifies somewhat and the Conscientiousness plateaus - indicating job-consistency and life-stability. 
Table-11: Showing the Pearson's Product-moment correlation coefficients indicating magnitude and direction of relationship between generativity and each of the other variables in the different age groups of female midlifers. Generativity

$p$ value

\begin{tabular}{l|l|l|l|l|}
\hline & Extraversion & $.485 * *$ & .000 \\
\cline { 2 - 4 } & & & \\
\hline & Conscientiousness & $.411^{* *}$ & .001 \\
\hline & Neuroticism -1 & -.234 & .065 \\
\hline & Openness to experience & .033 & .799 \\
\hline & Agreeableness & -.019 & .884 \\
\hline & Neuroticism & .010 & .931 \\
\hline & Extraversion & $.333^{* *}$ & .002 \\
\hline & Openness to experience & $.358^{* *}$ & .001 \\
\hline & Agreeableness & $.240 *$ & .030 \\
\hline & Conscientiousness & $.348^{* *}$ & .001 \\
\hline & Neuroticism & $-.358^{* *}$ & .006 \\
\hline & Openness to experience & .135 & .316 \\
\hline & Agreeableness & .245 & .066 \\
\hline & Conscientiousness & $.328 *$ & .013 \\
\hline & Extraversion & .272 & .041 \\
\hline
\end{tabular}

Table-12: Showing the Pearson's product- moment correlation coefficients indicating magnitude and direction of relationship between generativity and each of the other variables in the different age groups of male midlifers. $(\mathrm{p}<0.05) ; * *(\mathrm{p}<0.01)$

\begin{tabular}{|c|c|l|l|}
\hline Male & Generativity & Pearson's $r$ & $p$ value \\
\hline Age Group-1 & Conscientiousnes & $.355^{*} *$ & .001 \\
& $\mathrm{~s}$ & & \\
\hline & Agreeableness & .117 & .284 \\
\hline & Neuroticism & .116 & .288 \\
\hline & Extraversion & .201 & .063 \\
\hline & Openness to experience & .146 & .179 \\
\hline Age Group-2 & Conscientiousnes & $.442^{* *}$ & .000 \\
& $\mathrm{~s}$ & & \\
\hline & Agreeableness & $.267^{*} *$ & .010 \\
\hline & Extraversion & $.332^{*} *$ & .001 \\
\hline & Neuroticism & -.112 & .289 \\
\hline & Openness to experience & .100 & .345 \\
\hline Age group -3 & Extraversion & $.223^{*}$ & .050 \\
\hline & Agreeableness & $.234^{*}$ & .039 \\
\hline & Neuroticism & -.161 & .159 \\
\hline & Openness to experience & .209 & .066 \\
\hline & Conscientiousness & .156 & .174 \\
\hline
\end{tabular}

Table- 13: Showing the relative contribution of the domains of personality on the generativity of three different age groups of the male middle adults by the Stepwise Multiple Regression Analysis (SMRA).

Personal Growth in Midlifers 37

\begin{tabular}{|l|l|l|l|l|l|l|}
\hline & Male & & & & & \\
\hline & $\begin{array}{l}\text { Significant contributory } \\
\text { variables }\end{array}$ & $\begin{array}{l}\text { Beta } \\
\text { value }\end{array}$ & $\mathrm{R}$ & $\begin{array}{l}\mathrm{R} \\
\text { square }\end{array}$ & $\begin{array}{l}\text { Adjusted } \\
\text { R square }\end{array}$ & $\mathrm{p}$-value \\
\hline $\begin{array}{l}\text { Age Group- } \\
1\end{array}$ & Conscientiousness & .368 & .355 & .126 & .116 & $<.01$ \\
\hline $\begin{array}{l}\text { Age group- } \\
2\end{array}$ & Conscientiousness & .300 & .530 & .281 & .265 & $<.01$ \\
\hline $\begin{array}{l}\text { Age group - } \\
3\end{array}$ & Openness to experience & .220 & .445 & .198 & .177 & $<.05$ \\
\hline
\end{tabular}

Table-14: Showing the relative contribution of the variables of personality and its different aspects, selfefficacy (SE) narcissism, psychiatric morbidity (PM) and marital quality (MQ) on the generativity of three different age groups of the female middle adults by the Stepwise Multiple Regression Analysis (SMRA).

\begin{tabular}{|l|l|l|l|l|l|l|}
\hline & & Female & & & & p-value \\
\hline & $\begin{array}{l}\text { Significant } \\
\text { Contributory } \\
\text { Variables }\end{array}$ & Beta value & $\mathrm{R}$ & $\begin{array}{l}\mathrm{R} \\
\text { square }\end{array}$ & $\begin{array}{l}\text { Adjusted } \\
\text { R square }\end{array}$ & \\
\hline Age Group-1 & Extraversion & .426 & .485 & .236 & .223 & $<.01$ \\
\hline Age group-2 & $\begin{array}{l}\text { Openness } \\
\text { To } \\
\text { experience }\end{array}$ & .237 & .609 & 371 & .355 & $<0.05$ \\
\hline
\end{tabular}


Thus, from the above discussion, a more explicit and comprehensive idea has emerged about midlife growth and development for the working middle adults. The different variables have acted and interacted upon midlife personal growth in crucial ways. The discussion has raised important questions that would definitely stimulate further exploration of this intriguing and unique phase of the life-span. The knowledge about factors contributing or disrupting midlife generativity would definitely create social benefits and would have far-fetched implications in the study of adult development.

\section{References}

[1]. Aldwin, C.M \& Levenson,M.R.,(2001), “ Stress, Coping \& Health at Midlife: A Developmental Perspective. In M.E. Lachman (Ed.), Handbook of Midlife Development (pp.279-309), New York: Wiley.

[2]. Baltes, P.B. (1987). Theoretical propositions of life-span developmental psychology: On the dynamics between growth and decline. Developmental Psychology,23,611-626. http://dx.doi.org/10.1037/0012-1649.23.5.611

[3]. Baltes, P.B., Lindenberger, U., \& Staudinger, U.M. (1997). Life - span theory in developmental psychology. In R.M. Lerner (Ed.), Handbook of child psychology: Theoretical models of human development (5 $5^{\text {th }}$ ed., Vol. 1, pp. 1029-1143). New York : Wiley.

[4]. Bengtson, V.L., Reedy, M.N., \& Gordon,C. (1985). Aging and self-conceptions : Personality processes and social contexts. In J.E. Birren \& K.W. Schaie (Eds.), Handbook of the psychology of aging ( $2^{\text {nd }}$ ed., pp. 544-593). New York : Van Nostrand - Reinhold

[5]. Bhattacharya,S.,Das, S., \& Basu,S. (2008). Meaning in life, Hope, Coping, \& Midlife well-being- A correlational study . Indian Journal of Clinical Psychology.

[6]. Bowlby, J. (1982). Attachment and loss (Vol.1), New York: Basic Books.

[7]. Chakraborty, N. \& Das,S.(2010). Generative Concern in Middle Adulthood Journal of Psychometry. Vol. 24 (2), 79-91.

[8]. Chakraborty, N., \& Das, S., (2012). Midlife and the Life-course- The associated shifts in life perspective and societal obligations. Indian Journal of Positive Psychology.Vol-3 (4),2012.

[9]. Clark-Plaskie, M.,\& Lachman, M.E.(1999). The sense of control in midlife. In S.L.Willis \& J.D.Reid (Eds.), Life in the middle. Psychological and social development in middle age (pp. 181-208). San Diego, CA: Academic Press.

[10]. Costa, P.T., \& McCrae, R. (1994). Sent like plaster? Evidence for stability of adult personality. In T.F. Heatherton \& S.L. Weinberger (Eds.), Can personality change? (pp.210440). Washington, DC : American Psychological Association.Personal Growth in Midlifers 39

[11]. Costa, P.T., Herbst, J.H., McCrae, R.R., \& Siegler, I.C, (2000). Personality at midlife: Stability, intrinsic maturation, and response to life events. Assessment, 7, 365-378.http://dx.doi.org/10.1177/107319110000700405

[12]. Costa,P.T., Jr., \& McCrae,R.R.(1992). The NEO Personality Inventory (NEO PI-R) and NEO FIVE - FACTOR Inventory (NEOFFI) Professional Manual .Florida: Psychological Assessment Resources, Inc.

[13]. Cross, S.E., \& Markus, H.R. (1991). Possible selves across the life span. Human Development, 34, 230255.http://dx.doi.org/10.1159/000277058

[14]. Crowley, B.J., Hayslip., B.J., \& Hobdy,J. (2003). Psychological hardiness and adjustment to life events in adulthood. Journal of Adult Development, 10, 237-248. http://dx.doi.org/10.1023/A:1026007510134

[15]. Diehl, M., Hastings, C.T., \& Stanton, J.M. (2001). Self-concept differentiation across the adult life span. Psychology and Aging, 16, 643-654.http://dx.doi.org/10.1037/0882-7974.16.4.643PMid:11766918

[16]. Dorner.J., Mickler.C. \& Staudinger.U.M. (2005). Self-Development at Midlife: Life-span perspectives on Adjustment and Growth. In S.L. Willis \& M.Martin (eds) Middle Adulthood: A Lifespan Perspective. http://dx.doi.org/10.4135/9781452225999.n9

[17]. Dudek S.Z., \& Hall, W.B. (1991). Personality consistency: Eminent architects 25 years later. Creativity Research Journal, 4, $213-$ 2321. http://dx.doi.org/10.1080/10400419109534395.

[18]. Erikson, E.H. (1950) - "Childhood and Society". New York: Norton Featherman, D.L., \& Lerner, R.M. (1985). Ontogenesis and sociogenesis : Problematics for theory and research about development and socialization across the lifespan. American Sociological Review, 50, 659-676. http://dx.doi.org/10.2307/2095380.

[19]. Haan, N. Millsap, R., \& Hartka, E (1986). As time goes by: Change and stability in personality over fifty years. Psychology and Aging, 1, 220-232. http://dx.doi.org/10.1037/0882-7974.1.3.220

[20]. Heckhausen, J. (1999). Development regulation in adulthood. Age - normative and socio-structural constraints as adaptive challenges. Cambridge, UK: Cambridge University Press.

[21]. Helson, R., \& Kwan, V.S.Y. (2000). Personality development in adulthood: The broad picture and processes in one longitudinal sample. In S. Hampson (Ed.), Advances in personality psychology (Vol. 1. pp. 77-106). London: Routledge. doi: 10.1037/a0014156

[22]. Personal Growth in Midlifers 40

[23]. Hooker, K., \& Kaus, C.R. (1994). Health - related possible selves in young and middle adulthood. Psychology and Aging, 9, 126133.http://dx.doi.org/10.1037/0882-7974.9.1.126 PMid:8185860

[24]. Jacques, E. (1965). Death and the midlife crisis. International journal of Psycho-analysis, 46, 502-514

[25]. James, W. (1890). The principles of psychology. New York: Dover. http://dx.doi.org/10.1037/11059-000.

[26]. John, O. P. \& Srivastava, S. (1999). The Big Five trait taxonouny : History, Measurement, and theoretical perspectives. In L.A. Pervin \& O.P. John (Eds) Handbook of personality theory and research (Vol. 2, pp. 102-138). New York Guilford Press.

[27]. Keyes, C.L.M., \& Ryff, C. D. (1999). Psychological well-being in mid-life. In S.L., Willis \& J.D. Reid (Eds), Life in the middle : Psychological and social development in middle age (pp. 161-182). San Diego, CA: Academic Press.

[28]. Kotre, J. (1984). Outliving the self: Generativity and the interpretation of lives. Baltimore : Johns Hopkins University Press.

[29]. Kotre, J. (1999). Making it count: How to generate a legacy that gives meaning to your life. New York: Free Press.

[30]. Lachman, M.E. (2004). Development in midlife. Annual Review of psychology, 55, 305331.http://dx.doi.org/10.1146/annurev.psych.55.090902.141521 PMid: 14744218.

[31]. Lachman, M.E., \& Baltes, P.B. (1994). Psychological aging in lifespan perspective. In M. Rutter \& D.F. Hay (Eds.), Development through life : A handbook for clinicians (pp. 583-606). London: Blackwell Scientific.

[32]. Lachman, M.E., \& James, J.B. (1997). Charting the course of midlife development: An overview. In M.E. Lachman \& J.B. James (Eds.). Multiple paths of midlife development (pp. 1-17). Chicago: University of Chicago Press.

[33]. Lachman.M.E. \& Bertrand,R.M. (2001).Personality and the Self in Midlife. In M.E. Lachman (Ed.), Handbook of Midlife Development (pp.279-309), New York: Wiley. 
[34]. Lansford, J.E., Sherman, A.M., \& Antonucci, T.C. (1998). Satisfaction with the social networks: An examination of socioemotional selectivity theory across cohorts. Psychology and Aging, 13, 544-552. http://dx.doi.org/10.1037/0882-7974.13.4.544 PMid:9883455. Personal Growth in Midlifers 41

[35]. Lerner, R.M. (1976). Concepts and theories of human development. Reading, MA: Addison-Wesley.

[36]. Levinson, D.J. (1977). The mid-life transition. Psychiatry, 40, 99-112. PMID:870922[PubMed - indexed for MEDLINE]

[37]. Markus, H.R., \& Lachman, M.E. (1996, September). Attributes and traits: Collective and individual approaches. Paper presented at the MIDMAC meeting, Cambridge, MA.

[38]. McAdams, D.P., \& de St. Aubin, E. (1992). A theory of generativity and its assessment through self-report, behavioral acts, and narrative themes in autobiography. Journal of Personality and Social Psychology, 62, 1003-1015. doi: 10.1037/00223514.62.6.1003

[39]. McAdams. D.P. (2001) Generativity in midlife in M.E. Lachman (Ed.), Handbook of midlife development (pp. 395-443). New York Wiley.

[40]. McAdams,D.P. \& Logan R.L.(Eds) (2004).Generative Society :Caring for Future Generations. Washington D.C: American Psychological Associations. http://dx.doi.org/10.1037/10622-002. PMID:8323726

[41]. McCrae, R. \& Costa, P.T. (1990) Personality in adulthood. New York: Guilford Press.

[42]. McCrae, R. \& Costa. P.T., Ostendorf, F., Angleitner, A., Hrebickova, M., Avia, M.D., et al. (2000). Nature over nurture : Temperament, personality, and life span development Journal of Personality and Social Psychology, 78, 173-186.

[43]. Mirowski,J.,\& Ross,C.E.(1999). Well being across the Life Course. In A.V.Horwitz \& T.L.Scheid (Eds), - "A Handbook for the Study of Mental Health: Social Contexts, Theories and Systems (pp.328-347), New York: Cambridge University Press.

[44]. Moran, G. (1998). Cares for the rising generation: Generativity in American history, 1607-1900. In D.P. McAdams \& E. de st. Aubin (Eds.), Generativity and adult development (pp. 311-333). Washington, DC: American Psychological Association.

[45]. Morfei, M.Z., Hooker, K., Carpenter, J., Mix, C., \& Blakeley, E. (2004). Agentic and communal generative behaviour in four areas of adult life: Implications for psychological well - being. Journal of Adult Development, 11, 55-58.

[46]. Morfei, M.Z., Hooker, K., Carpenter, J., Mix, C., \& Blakeley, E. (2004). Agentic and communal generative behaviour in four areas of adult life: Implications for psychological well - being. Journal of Adult Development, 11, 55-58. http://dx.doi.org/10.1023/B:JADE.0000012528.25409.aaPersonal Growth in Midlifers 42

[47]. Neugarten,B.L. (1968). The Awareness of Middle age. In B.L.Neugarten(Ed), "Middle Age and Ageing". A Reader in Social Psychology ( pp.93-98).Chicago: University of Chicago Press.

[48]. Neugarten, B.L. (1977). Personality and aging. In J.E. Birren \& K.W. Schaie (Eds.) Handbook of the psychology of aging (pp. 626649). New York. Van Nostrand Reinhood.

[49]. Peck, R.C. (1956). Psychological developments in the second half of life. In J.E. Anderson (Ed.), Psycholgoical aspects of aging (pp. 44-49). Washington, DC: American Psychological Association.

[50]. Peterson, B.E., \& Klohnen, E.C. (1995). Realization of generativity in two samples of women at midlife. Psychology an Aging, 10, 29-29. PMID:7779312 [PubMed - indexed for MEDLINE

[51]. Peterson, B.E., \& Stewart, A.J. (1996). Antecedents and contexts of generativity motivation at midlife. Psychology and Aging, 11, 21-33.

[52]. Piaget, J. (1974). The origins of intelligence in children (M. Cook, Trans). New York: International Universities Press. (Original work published 1936).

[53]. Reid,J.D. \& Willis, S.L.(1999) Middle Age: New Thoughts New Directions. In S.L.Willis and J.D.Reid (Eds), Life in the Middle; Psychological and Social Development in Middle Age (pp.276-280). San Diego, CA: Academic Press.

[54]. Roberts, B.W., \& Friend, W. (1998). Career momentum in midlife women: Life context, identity, and personality correlates. Journal of Occupational Health Psychology, 3, 195-208. .http://dx.doi.org/10.1037/1076- 8998.3.3.195 PMid:9684211.

[55]. Roberts, B.W., Robins, R.W., Caspi, A., \& Trzesniewski, K.H. (2003). Personality trait development in adulthood. In J.L. Mortimer \& M. Shanahn (Eds), Handbook of the life course (pp. 570-598). New York: Kluwer Academic.

[56]. Roberts,B.W., \& DelVecchio,W.F.(2000). The Rank Order Consistency of Personality Traits from Childhood to Old Age: A Quantitative Review of Longitudinal Studies. Psychological Bulletin, 126. 3-25. http://dx.doi.org/10.1037/0033-2909.126.1.3.

[57]. Robins, R.W., Trzesniewski, K.H., Tracy, J.L., Gosling, S.D., \& Potter, J. (2002). Global self-esteem across the life span. Psychology and Aging, 17, 423-434. http://dx.doi.org/10.1037/0882-7974.17.3.423 PMid:12243384.

[58]. Rossi, A.(Ed).(2001). Caring and Doing for Others: Social Responsibility in the Domains of Family, Work and Community. Chicago: University of Chicago press.Personal Growth in Midlifers 43

[59]. Rousseau, J.J. (1948). Emile or education (B. Foxley, Trans). London: J.M.. Dent and Sons Limited. (Original work published 1762).

[60]. Santrock,W.J.,(.1997). Socio-emotional development in middle adulthood. Life-Span Development, Sixth Edition,Brown and benchmark publishers.

[61]. Snarey, J. (1993). How fathers care for the next generation. Cambridge. MA : Harvard University Press.

[62]. Snarey, J., Son, L., Kuchne, V.S., Hauser, S., \& Vaillant, G. (1987). The role of parenting in men's psychological development: A longitudinal study of early adulthood infertility and midlife generativity. Developmental Psychology, 23, 593-603. http://dx.doi.org/10.1037/0012-1649.23.4.593.

[63]. Srivastava, S., John, O.P., Gosling, S. \& Potter, J. (2003). Development of personality in early and middle adulthood : Set like plaster or persistent change? Journal of personality and social Psychology 984, 1041-10953.

[64]. doi.10.1037/0022-3514.84.5.1041

[65]. Staudinger, U.M., \& Bluck, S. (2001), A view on midlife development from lifespan theory. In M.E. Lachman (Ed.,), Handbook of midlife development (pp. 3-39). New York : Wiley.

[66]. Stewart, A.J., \& Ostrove, J.M. (1998). Women's personality in middle age : Gender, history, and midcourse corrections. American Psychologist,53,1185-1194.http://dx.doi.org/10.1037/0003-066X.53.11.1185PMid:9830371.

[67]. Stewart, A.J., \& Vandewater, E.A. (1998). The course of generativity. In D.P.McAdams \& E. de St. Aubin (Eds.), Generativity and adult development : Psychosocial perspectives on caring for and contributing to the next generation (pp.75-100). Washington, DC : American Psychological Association Press.

[68]. Vaillant, G.E. (1977). Adaptation to life. Boston : Little, Brown.

[69]. Vaillant, G.E., \& Milofsky, E. (1980). Natural history of male psychological health IX : Empirical evidence for Erikson's model of the life cycle. American Journal of Psychiatry, 137, 1348-1359. PMID: 7435667 [PubMed - indexed for MEDLINE]

[70]. Willis, S.L., \& Martin, M. (2005) .Middle Adulthood- A Life-span Perspective.Thousand Oaks, Sage Publications. 